\title{
Sistem Pendukung Keputusan Penerima Bantuan Rumah Tak Layak Huni (RTLH) Di Kota Binjai Dengan Metode Simplemultiple Attribute Rating Technique (SMART) (STUDI KASUS: DINAS SOSIAL BINJAI)
}

\author{
Yustika Indah Purwanti ${ }^{1}$, Budi Serasi Ginting ${ }^{2}$, Novriyenni ${ }^{3}$ \\ STMIK Kaputama Binjai, Jl. Veteran No. 4A-9A, Binjai, Sumatera Utara, Indonesia \\ yustikaindahpurwanti12@gmail.com ${ }^{1 *}$, budiserasiginting910@gmail.com² ${ }^{2}$,novri_yenni@gmail.com ${ }^{3}$
}

\begin{abstract}
Abstrak. Sistem pendukung keputusan didefinisikan sebagai sebuahsistem yang dimaksudkan untuk mendukung para pengambil keputusan manajerial dalam situasi situasi tertentu. Sistem pendukung keputusan dimaksudkan untuk menjadi alat bantu bagi para pengambil keputusan untuk memperluas kapabilitas mereka, namun tidak untuk menggantikan penilaian mereka. Bantuan RTLH (Rumah Tak Layak Huni) ini harus dapat tepat sasaran kepada penduduk tidak mampu yang memenuhi kriteria-kriteria sebagai syarat penerima bantuan RTLH, sehingga penduduk tidak mampu penerima bantuan RTLH dapat menerima bantuan tersebut. Dalam pelaksanaanya, penduduk tidak mampu yang berhak menerima bantuan tidak layak huni ditentukan oleh Dinas Sosial (Dinsos). Salah satu metode dalam pendukung keputusan adalah metode Simple Multi Attribute Rating Technique (SMART) atau biasa disingkat dengan metode SMART. Metode SMART adalahmetode yang memiliki perhitungan dengan kalkulasi yang minimum dan sangat sederhana, tetapi objektifterhadap hasil pendukung keputusan. Dari penelitian yang dilakukan dengan metode SMART didapatkan bahwa R9 dengan nilai optimasi akhir 0, 725 menjadi penerima bantuan rumah tak layak huni dari 10 alternatif data rumah tak layak huni yang dianalisa.
\end{abstract}

Kata Kunci : Bantuan, RTLH, SMART.

Abstract. Decision support system is defined as a system that is intended to support managerial decision makers in certain situations. Decision support systems are intended to be a tool for decision makers to expand their capabilities, but not to replace their judgment. This RTLH (Unfit for Living House) assistance must be right on target for poor people who meet the criteria as requirements for receiving RTLH assistance, so that residents who are unable to receive $R T L H$ assistance can receive the assistance. In its implementation, the underprivileged population who is entitled to receive assistance unfit for habitation is determined by the Social Service (Dinsos). One of the methods in decision support is the Simple Multi Attribute Rating Technique (SMART) method or commonly abbreviated as the SMART method. The SMART method is a method that has minimum calculations and is very simple, but objective on the results of decision support. From research conducted using the SMART method, it was found that $R 9$ with a final optimization value of 0.725 became the recipient of uninhabitable housing assistance from 10 alternative data on uninhabitable houses analyzed..

Keyword: Help, RTLH, SMART.

\section{PENDAHULUAN}

Rumah sebagai salah satu kebutuhan dasar manusia menjadi kebutuhan yang harus diperhatikan karena menyangkut kesejahteraan masyarakat. Kebutuhan akan rumah layak huni semangkin meningkat, namun tidak seiring dengan meningkatnya taraf hidup masyarakat ekonomi lemah yang mengharuskan hidup dalam rumah yang tidak layak huni[1], [2].

Bantuan RTLH (Rumah Tak Layak Huni) merupakan program pemerintah yang berupa bantuan dana untuk perbaikan rumah yang tidak layak huni. Bantuan RTLH ini harus dapat tepat sasaran kepada penduduk tidak mampu yang memenuhi kriteria-kriteria sebagai syarat penerima bantuan RTLH,sehingga penduduk tidak mampu penerima bantuan RTLH dapat menerima bantuan tersebut. Dalam pelaksanaanya, penduduk tidak mampu yang berhak menerima bantuan tidak layak huni ditentukan oleh Dinas Sosial (Dinsos). Untuk menentukan layak tidaknya,penduduk harus memenuhi kriteria yang telah ditentukan yaitu luas ruangan, kondisi fisik rumah, pendapatan pemilik 
rumah, jumlah anggota keluarga, dan pekerjaan[1]-[3]. Akan tetapi pihak penentuan dalam hal ini yaitu pihak Dinas Sosial masih mengalami kesulitan seperti dalam pengolahan datanya membutuhkan ketelitian, sehingga memungkinkan terjadinya rangkap data juga terjadinya kesalahan dalam penentuan penduduk yang harus diutamakan,sehingga diperlukan suatu sistem pendukung keputusan yang dapat membantu dalam menentukan siapa yang berhak didahulukan dalam mendapatkan bantuan RTLH (Rumah Tak Layak Huni).

Salah satu metode yang cocok digunakan untuk sistem pendukung keputusan ini adalah Metode Simple Multi Attribut Rating Technique (SMART) yang merupakan suatu metode pengambilan keputusan multi kriteria yang didasarkan pada teori bahwa setiap alternatif terdiri dari sejumlah kriteria yang memiliki nilai dan setiap kriteria memiliki bobot untuk menggambarkan seberapa penting nilainya dibandingkan dengan kriteria yang lain [4]. Metode smart lebih sering digunakan karena kesederhanaannya dalam merespon kebutuhan pembuat keputusan dan menganalisa respon. Metode ini digunakan karena mampu menyelesaikan rekomendasi dari kasus multi kriteria dalam penentuan calon penerima bantuan RTLH.

Sistem pendukung keputusan yang terkomputerisasi merupakan solusi dari permasalahan yang terjadi pada Dinas Sosial dalam menetukan penerima bantuan RTLH. Dengan menerapkan metode SMART (Simple Multiple Attribute Rating Technique) terbukti berhasil dalam menghasilkan keputusan yang tepat dan objektif. Seperti penelitian yang berjudul "Implementasi Sistem Pendukung Keputusan dengan Metode SMART untuk Merangking Kemiskinan dalam Proses Penentuan Penerima Bantuan PKH". Hasil penelitiannya adalah metode SMART berhasil menyelesaikan masalah seleksi penerima bantuan PKH secara objektif dengan hasil 20 orang yang berhasil masuk dalam desil 1 dan 5 orang yang menjadi calon penerima bantuan PKH [5]. Selain itu juga ada penelitian lainnya yang berjudul "Implemtasi Metode SMART pada Sistem Pendukung Keputusan Pemilihan Kegiatan Ekstrakurikuler untuk Siswa SMA". Metode SMART yang digunakan pada pembuatan sistem pendukung keputusan kegiatan ekstrakurikuler ini mampu membantu siswa dalam memberikan keputusan pemilihan kegiatan ekstrakurikuler dengan tingkat akurasi pengujian sebesar $84,39 \%$ [6].

\section{METODOLOGI PENELITIAN}

DSS merupakan sistem informasi interaktif yang menyediakan informasi, pemodelan dan pemanipulasian data. Sistem itu digunakan untuk membantu pengambilan keputusan dalam situasi yang semiterstruktur dan situasi yang tidak terstruktur, dimana tidak seorang pun tahu sacara pasti bagaimana keputusan seharusnya dibuat [7].

\subsection{Penelitian Terdahulu}

Pada penelitian ini peneliti menggunakan beberapa referensi yang semuanya membahas tentang sistem pendukung keputusan dengan metode yang sama yaitu metode Simple Multi Attribute Rating (SMART) untuk membandingkan perbedaan penelitian yang akan dibuat dengan penelitian yang sudah adaDalam penelitian ini terdapat jurnal pendukung dalam penerapan metode Simple Multi Attribute Rating Tehnique (SMART)..Masalah yang diteliti yaitu Program Keluarga Harapan (PKH) merupakan salah satu program percepatan penanggulangan kemiskinan dan pengembangan sistem jaminan sosial melalui pemberian bantuan tunai bersyarat kepada Rumah Tangga Sangat Miskin (RTSM). Dengan banyaknya data yang diolah di indonesia, maka diperlukan sebuah sistem pendukung keputusan untuk memudahkan pembuat keputusan menentukan calon penerima bantuan PKH. Sehingga dibutuhkan suatu sistem yang dapat memberikan solusi terbaik dalam penentuan masyarakat yang berhak mendapat bantuan Program Keluarga Harapan(PKH)[5]. Kesimpulan yang ditulis peneliti yaitu bahwa Metode Simple Multi Attribute Rating Technique (SMART) yaitu metode pengambilan keputusan multi kriteria dapat digunakan sebagai salah satu metode untuk pengambilan

Sistem Pendukung Keputusan Penerima Bantuan Rumah Tak Layak Huni (RTLH) Di Kota Binjai Dengan Metode Simplemultiple Attribute Rating Technique (SMART) 
suatu keputusan untukmenentukan calon penerima bantuan $\mathrm{PKH}$, dimana kriteria yang digunakan adalah penghasilan, jumlah tabungan, luas bangunan, jenis lantai, jenis dinding, biaya pengobatan, makan sehari-hari, konsumsi daging/susu/ayam,fasilitas buang air besar, beli pakaian dalam 1 tahun,sumber penerangan,sumber air bersih, bahan bakar memasak, pendidikan krt. Semakin banyak kriteria yang digunakan maka akan mendapatkan nilai semakin baik. Selain kriteria, pemberian bobot dan sub kriteria juga mempengaruhi perhitungan, pemberian bobot yang masih menggunakan nilai yang sama dapat membuat nilai total akan muncul nilai yang sama juga dan pemberian sub kriteria yang sedikit membuat masukan setiap peserta akan sama. Penelitian tentang kegiatan ekstrakurikuleryang ada pada sekolah tersebut membuat siswa sulit untuk menentukan kegiatan ekstrakurikuler apa yang harusdiikuti, sehingga tidak jarang siswa tersebut salah memilih ekstrakurikuler dan tidak sesuai dengan potensi yangmereka miliki[8]. Pemilihan kegiatan eksktrakurikuler dengan menggunakan Metode SMART ini melibatkan beberapa kriteria diantaranya minat,bakat/kemampuan, jadwal latihan, serta prestasi ekstrakurikuler. Pemilihan eksktrakurikuler yangbersifat lebih kepada pribadi siswanya akanmembuat hasil yang didapat menjadi lebih sesuai dengan keinginan siswa tersebut. Sehingga akan mengurangi jumlah siswa tergolong salah dalam memilih ekstrakurikuler yang sesuai. Penentuan kriteria yang digunakan didasarkan pada situs resmi yaitu situs organisasi.org, dimana setelah kriteria ditentukan selanjutnya dilakukan wawancara ke sekolah dan menyebarkan kuisioner kepada siswa untuk melihat kriteria tersebut telah sesuai dengan kebutuhan siswa.

\subsection{Sistem Pendukung Keputusan}

Pengambilan keputusan merupakan proses pemilihan alternative tindakan untuk mencapai tujuan atau sasaran tertentu. Pengambilan keputusan dilakukan dengan pendekatan sistematis terhadap permasalahan melaui proses pengumpulan data menjadi informasi serta ditambah dengan factor-faktor yang perlu dipertimbangkan dalam pengambilan keputusan. Sistem pendukung keputusan atau Decision Support System (DDS) adalah sistem informasi interaktif yang menyediakan informasi, pemodelan, dan pemanipulasian data yang digunakan untuk membantu pengambilan keputusan pada situasi yang semi terstruktur dan situasi yang tidak terstruktur dimana tidak seorang pun tahu secara pasti bagaimana keputusan seharusnya dibuat[7], [9]-[11].

\subsection{Metode SMART}

Metode Simple Multi Attribute Rating Technique (SMART) merupakan metode dalam pengambilan keputusan multi atribut. Teknik pengambilan keputusan multi atribut ini digunakan untuk mendukung pembuat keputusan dalam memilih beberapa alternatif. Teknik pengambilan keputusan multi kriteria ini didasarkan pada teori bahwa setiap alternatif terdiri dari sejumlah kriteria yang memiliki nilai-nilai dan setiap kriteria memiliki bobot yang menggambarkan seberapa penting dibandingkan dengan kriteria lain. Pembobotan ini digunakan untuk menilai setiap alternatif agar diperoleh alternatif terbaik [5].

\section{HASIL DAN PEMBAHASAN}

Penelitian dilakukan pada Kantor Dinas Sosial Kota Binjai. Dalam penelitian ini penulis melakukan pelitian penerima bantuan rumah tak layak huni yang tepat di kota binjai. Bantuan sosial RLTH adalah pemberian bantuan stimulan berupa uang untuk pembelian bahan bangunan guna pemugaran Rumah Tidak Layak Huni dari pemerintah daerah kepada individu, keluarga, kelompok dan atau masyarakat yang sifatnya tidak secara terus menerus dan selektif yang bertujuan untuk melindungi dari kemungkinan

\subsection{Perhitungan SMART}

Sistem Pendukung Keputusan Penerima Bantuan Rumah Tak Layak Huni (RTLH) Di Kota Binjai Dengan Metode Simplemultiple Attribute Rating Technique (SMART) 


\section{Menentukan Kriteria Keputusan}

layak huni :

Berikut ini adalah kriteria yang digunakan dalam menetukan penerima bantuan rumah tak

Tabel 1. Tabel Kriteria Keputusan

\begin{tabular}{|l|l|l|}
\hline Kode Kriteria & Kriteria & Jenis \\
\hline K1 & Kondisi Fisik Rumah & Binefit \\
\hline K2 & Luas Rumah & Binefit \\
\hline K3 & Jumlah Anggota Keluarga & Binefit \\
\hline K4 & Pendapatan Kepala Keluarga & Binefit \\
\hline K5 & Pekerjaan Kepala Keluarga & Binefit \\
\hline
\end{tabular}

\section{Transformasi Data Alternatif}

Transformasi data alternatif RTLH dapat dilihat pada tabel berikut :

Tabel 2. Data Tansformasi Alternatif Data Rumah Tak Layak Huni

\begin{tabular}{|l|c|c|c|c|c|}
\hline \multirow{2}{*}{ Alternatif } & \multicolumn{5}{|c|}{ Kriteria } \\
\cline { 2 - 6 } & K1 & K2 & K3 & K4 & K5 \\
\hline R1 & 25 & 25 & 35 & 20 & 30 \\
\hline R2 & 30 & 20 & 25 & 30 & 15 \\
\hline R3 & 25 & 20 & 25 & 30 & 10 \\
\hline R4 & 25 & 25 & 35 & 20 & 10 \\
\hline R5 & 10 & 5 & 40 & 30 & 15 \\
\hline R6 & 25 & 15 & 35 & 30 & 45 \\
\hline R7 & 20 & 25 & 35 & 30 & 45 \\
\hline R8 & 20 & 15 & 40 & 20 & 15 \\
\hline R9 & 30 & 25 & 25 & 30 & 45 \\
\hline R10 & 30 & 20 & 25 & 40 & 15 \\
\hline
\end{tabular}

\subsection{Menetukan Nilai Utility}

Menentukan nilai utility dengan menggunakan persamaan $u j(a i)=\frac{(\mathrm{Cout}-\mathrm{C} \text { min })}{(\mathrm{C} \max -\mathrm{C} \min )}$ perhitungan nilai utility dengan persamaan tersebut adalah sebagai berikut : Persamaan $: u j(a i)=\frac{(\text { Cout }-\mathrm{C} \min )}{(\mathrm{C} \max -\mathrm{C} \min )}$

$\mathrm{K} 1$ :

$\mathrm{Cmax}=\{25 ; 30 ; 25 ; 25 ; 10 ; 25 ; 20 ; 20 ; 30 ; 30\}=30$

$\mathrm{Cmin}=\{25 ; 30 ; 25 ; 25 ; 10 ; 25 ; 20 ; 20 ; 30 ; 30\}=10$

$\mathrm{u}(\mathrm{K} 1)(\mathrm{R} 1)=\frac{(\text { Cout }-\mathrm{C} \text { min })}{(\mathrm{C} \max -\mathrm{C} \min )}=\frac{(25-10)}{(30-10)}=\frac{15}{20}=0,75$

$\mathrm{u}(\mathrm{K} 1)(\mathrm{R} 2)=\frac{(\text { Cout }-\mathrm{C} \min )}{(\mathrm{C} \max -\mathrm{C} \min )}=\frac{(30-10)}{(30-10)}=\frac{20}{20}=1$

$\mathrm{u}(\mathrm{K} 1)(\mathrm{R} 3)=\frac{(\text { Cout }-\mathrm{C} \text { min })}{(\text { Cmax }-\mathrm{Cmin})}=\frac{(25-10)}{(30-10)}=\frac{15}{20}=0,75$

$\mathrm{u}(\mathrm{K} 1)(\mathrm{R} 4)=\frac{(\text { Cout }-\mathrm{C} \text { min })}{(\mathrm{C} \max -\mathrm{C} \min )}=\frac{(25-10)}{(30-10)}=\frac{15}{20}=0,75$

$\mathrm{u}(\mathrm{K} 1)(\mathrm{R} 5)=\frac{(\text { Cout }-\mathrm{C} \text { min })}{(\mathrm{C} \text { max }-\mathrm{C} \text { min })}=\frac{(10-10)}{(30-10)}=\frac{0}{20}=0$ 


$$
\begin{aligned}
& \mathrm{u}(\mathrm{K} 1)(\mathrm{R} 6)=\frac{(\text { Cout }-\mathrm{C} \text { min })}{(\text { Cmax }-\mathrm{C} \text { min })}=\frac{(25-10)}{(30-10)}=\frac{15}{20}=0,75 \\
& \mathrm{u}(\mathrm{K} 1)(\mathrm{R} 7)=\frac{(\text { Cout }-\mathrm{C} \text { min })}{(\text { Cmax }-\mathrm{C} \text { min })}=\frac{(20-10)}{(30-10)}=\frac{10}{20}=0,5 \\
& \mathrm{u}(\mathrm{K} 1)(\mathrm{R} 8)=\frac{(\text { Cout }-\mathrm{C} \text { min })}{(\text { Cmax }-\mathrm{C} \text { min })}=\frac{(20-10)}{(30-10)}=\frac{10}{20}=0,5 \\
& \mathrm{u}(\mathrm{K} 1)(\mathrm{R} 9)=\frac{(\text { Cout }-\mathrm{C} \text { min })}{(\text { Cmax }-\mathrm{C} \text { min })}=\frac{(30-10)}{(30-10)}=\frac{20}{20}=1 \\
& \mathrm{u}(\mathrm{K} 1)(\mathrm{R} 10)=\frac{(\text { Cout }-\mathrm{C} \text { min })}{(\text { Cmax }-\mathrm{C} \text { min })}=\frac{(30-10)}{(30-10)}=\frac{20}{20}=1
\end{aligned}
$$

\begin{tabular}{|c|c|c|c|c|c|}
\hline \multirow{2}{*}{ Alternatif } & \multicolumn{4}{|c|}{ Kriteria } & \\
\hline & K1 & $\mathrm{K} 2$ & K3 & $\mathrm{K} 4$ & $\mathrm{~K} 5$ \\
\hline $\mathrm{R} 1$ & 0,75 & 1 & 0,666667 & 0 & 0,571429 \\
\hline $\mathrm{R} 2$ & 1 & 0,75 & 0 & 0,5 & 0,142857 \\
\hline R3 & 0,75 & 0,75 & 0 & 0,5 & 0 \\
\hline $\mathrm{R} 4$ & 0,75 & 1 & 0,666667 & 0 & 0 \\
\hline $\mathrm{R} 5$ & 0 & 0 & 1 & 0,5 & 0,142857 \\
\hline R6 & 0,75 & 0,5 & 0,666667 & 0,5 & 1 \\
\hline R7 & 0,5 & 1 & 0,666667 & 0,5 & 1 \\
\hline $\mathrm{R} 8$ & 0,5 & 0,5 & 1 & 0 & 0,142857 \\
\hline R9 & 1 & 1 & 0 & 0,5 & 1 \\
\hline R10 & 1 & 0,75 & 0 & 1 & 0,142857 \\
\hline
\end{tabular}

Hasil perhitungan nilai utility diatas dapat dilihat pada tabel berikut :

Tabel 3. Tabel Hasil Perhitungan Nilai Utility

\subsection{Perankingan Nilai Akhir Keputusan}

Hasil dari perhitungan nilai akhir kemudian diurutkan dari nilai yang terbesar hingga yang terkecil, alternatif dengan nilai akhir yang terbesar menunjukkan alternatif yang terbaik. Hasil perangkingan nilai akhir keputusan sebagai berikut :

Tabel 4. Tabel Perangkingan Nilai Akhir

\begin{tabular}{|l|l|l|c|}
\hline Alternatif & Hasil Akhir Keputusan & $\begin{array}{l}\text { Presentase } \\
\text { Keputusan }\end{array}$ & Peringkat \\
\hline R9 & 0,725 & $12,19341 \%$ & 1 \\
\hline R7 & 0,708333333 & $11,9131 \%$ & 2 \\
\hline R1 & 0,66547619 & $11,19231 \%$ & 3 \\
\hline R6 & 0,658333333 & $11,07218 \%$ & 4 \\
\hline R10 & 0,651785714 & $10,96206 \%$ & 5 \\
\hline R4 & 0,608333333 & $10,23125 \%$ & 6 \\
\hline R2 & 0,576785714 & $9,700671 \%$ & 7 \\
\hline R8 & 0,532142857 & $8,949845 \%$ & 8 \\
\hline R3 & 0,4875 & $8,199019 \%$ & 10 \\
\hline R5 & 0,332142857 & $5.586145 \%$ & 9 \\
\hline
\end{tabular}

Tampilan dari sistem penerima bantuan rumah tak layak huni yang telah dibangun dengan bahasa pemerograman PHP dengan basis data PHPMySQL adalah sebagai berikut : 


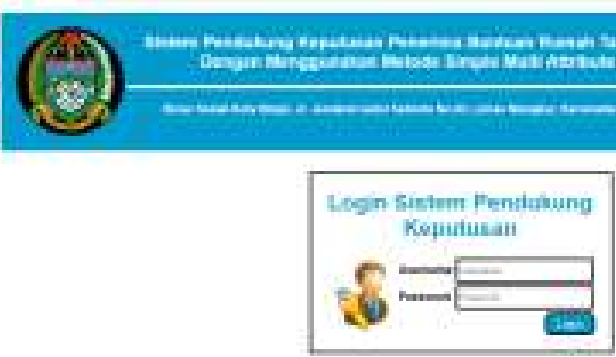

Gambar 1. Menu Tampilan Login Sistem
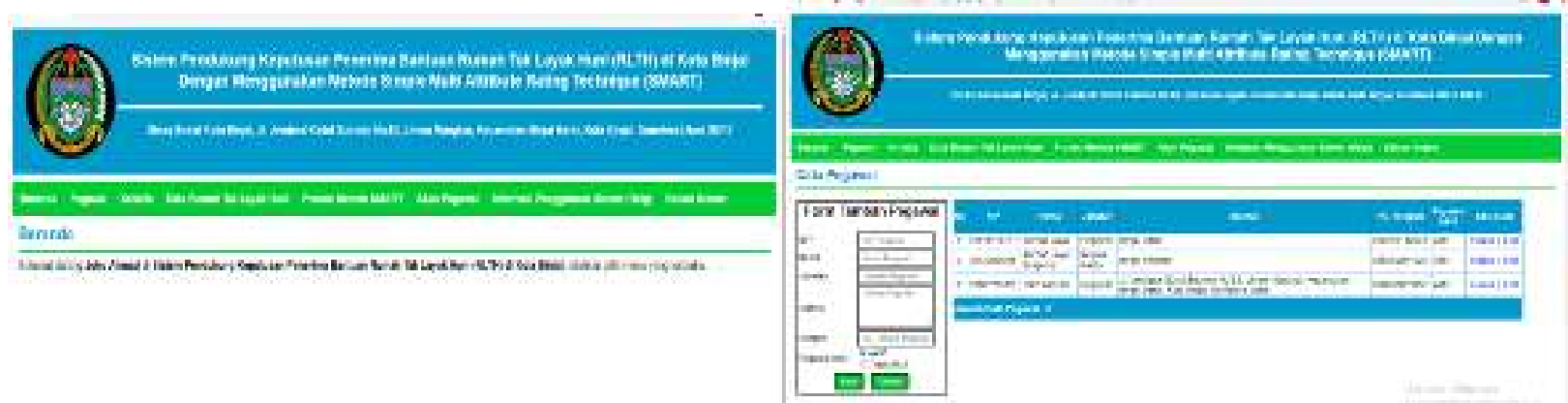

Gambar 2. Tampilan Halaman Utama Sistem dan Halaman Pegawai

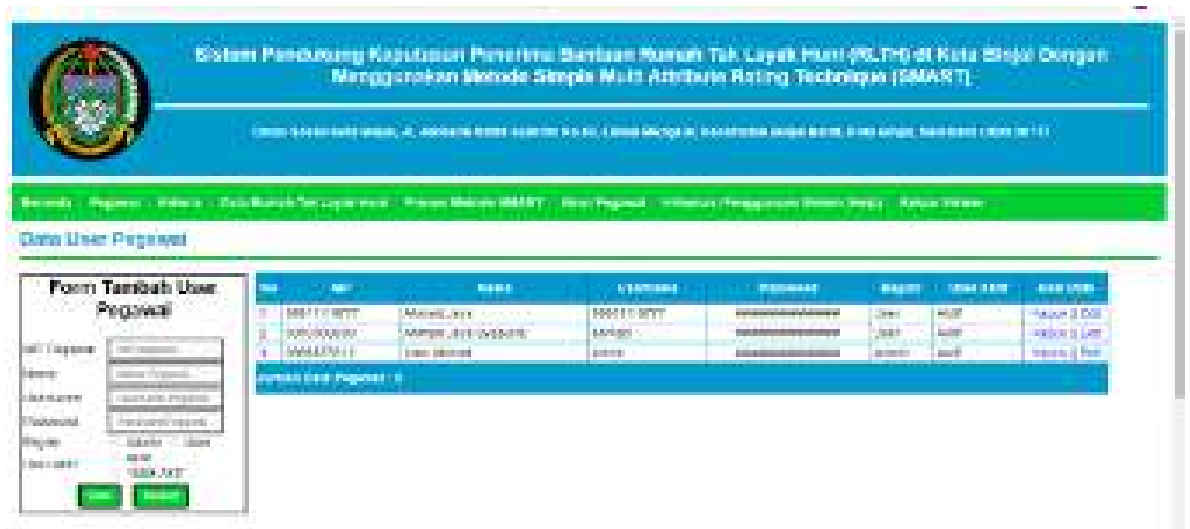

Gambar 3. Tampilan Halaman User Pegawai

1. Tampilan Halaman Kriteria Keputusan

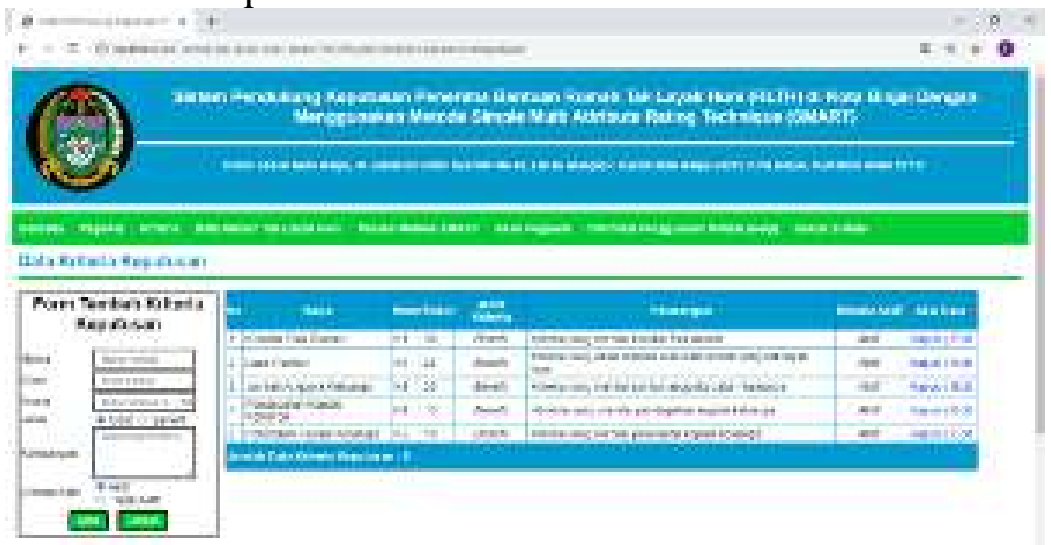

Gambar 4. Tampilan Halaman Kriteria Keputusan

Sistem Pendukung Keputusan Penerima Bantuan Rumah Tak Layak Huni (RTLH) Di Kota Binjai Dengan Metode Simplemultiple Attribute Rating Technique (SMART) 


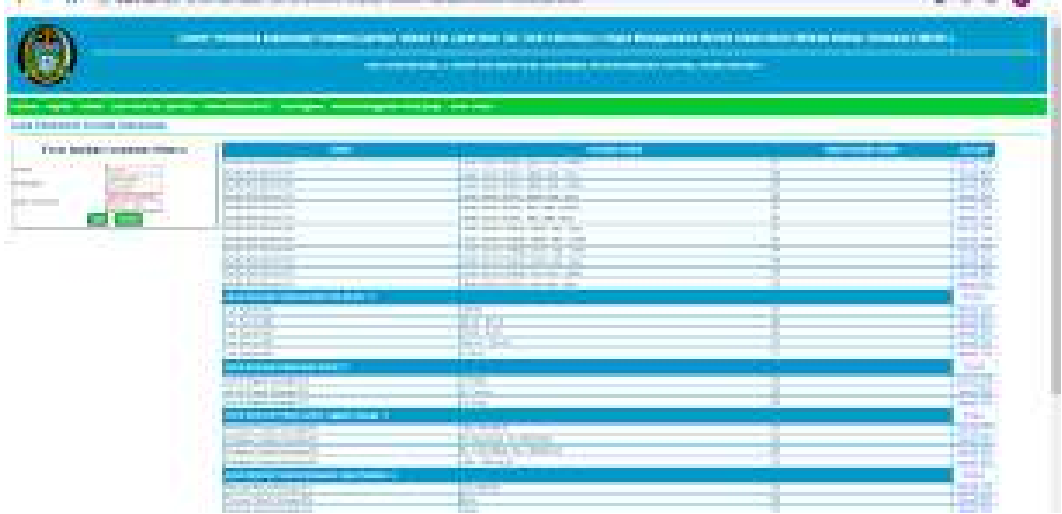

Gambar 5. Tampilan Halaman Parameter Kriteria Keputusan

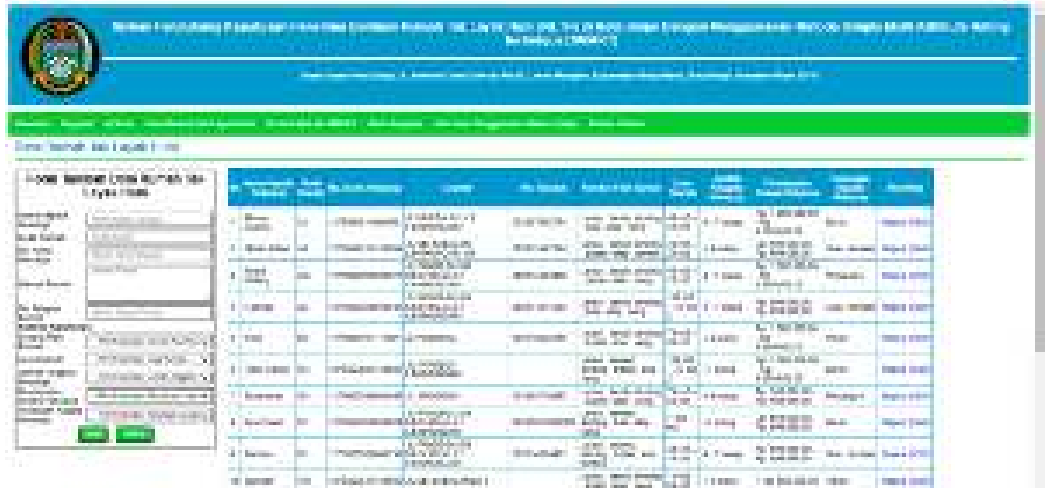

Gambar 6. Tampilan Halaman Alternatif DataRumah Tak Layak Huni

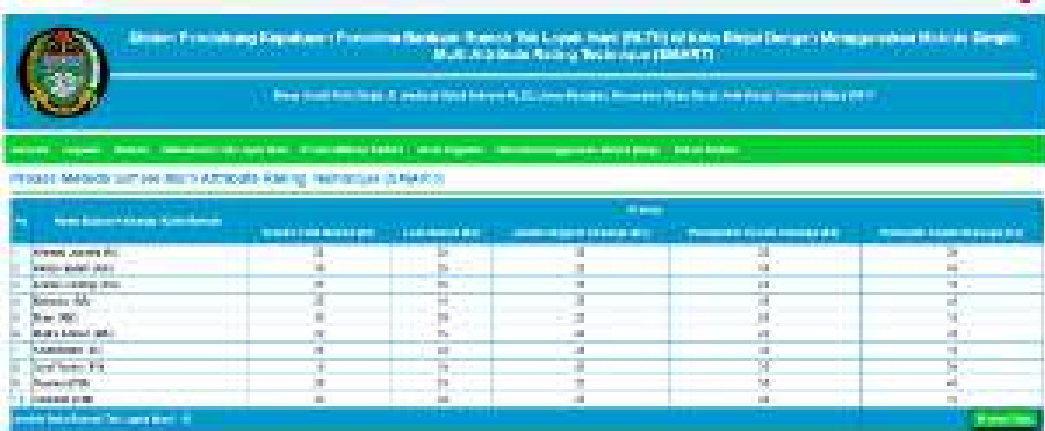

Gambar 7. Tampilan Halaman Proses Keputusan Metode SMART

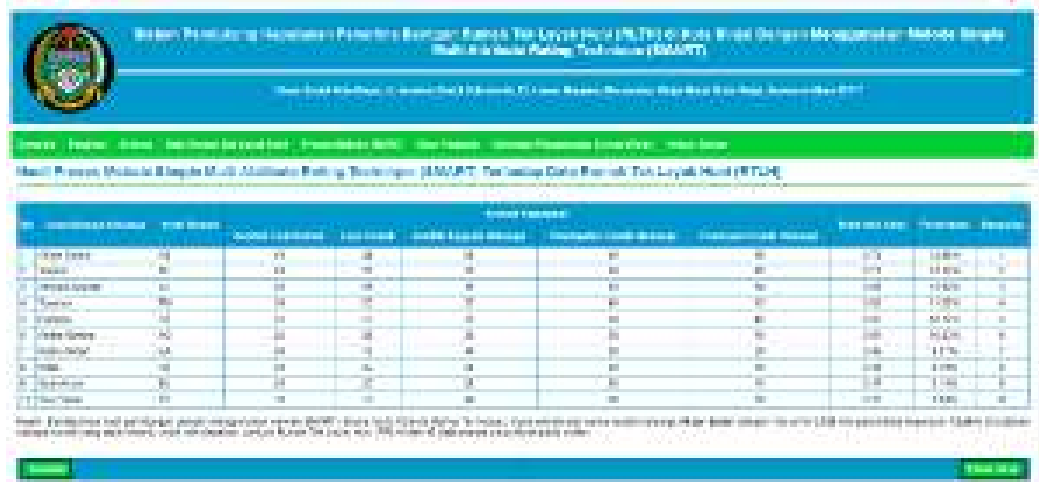

Gambar 8. Tampilan Halaman Hasil Keputusan Metode SMART

Sistem Pendukung Keputusan Penerima Bantuan Rumah Tak Layak Huni (RTLH) Di Kota Binjai Dengan Metode Simplemultiple Attribute Rating Technique (SMART) 


\section{KESIMPULAN}

Setelah melakukan pembahasan dan penguraian pada bab-bab sebelumnya, maka penulis memberikan beberapa kesimpulan. Berikut ini adalah kesimpulan yang penulis tulis pada penelitian ini terkait dengan sistem pendukung keputusan penerima bantuan rumah tak layak huni dengan metode SMART (Simple Multi Attribut Rating Technique), yaitu :

1. Kriteria yang tepat untuk sistem pendukung keputusan yang tepat dalam menentukan penerima bantuan rumah tak layak huni adalah kondisi fisik rumah (K1), luas rumah (K2), jumlah anggota keluarga (K3) dan pendapatan kepala keluarga (K4).

2. Pengujian terhadap metode SMART (Simple Multi Attribut Rating Technique) untuk sistem pendukung keputusan penerima bantuan rumah tak layak huni memanfaatkan 10 data alternatif sebagai analisa, dan berhasil menetapkan R9 dengan total hasil akhir 0,725; maka dapat dinyatakan bahwa R9 adalah penerima bantuan rumah tak layak huni yang tepat dipilih untuk mendapatkan bantuan dari 10 alternatif data rumah tak layak huni yang dianalisa. Perancangan sistem dilakukan untuk mempermudah pengguna dalam menggunakan sistem.

3. Hasil uji coba terhadap sistem yang telah dibangun dengan bahasa pemrograman PHP dengan basis data MySQL telah berhasil menentukan penerima bantuan rumah tak layak huni yang tepat dengan R9 sebagai data penerima bantuan rumah tak layak huni yang tepat dipilih.

\section{DAFTAR PUSTAKA}

[1] pu.go.id, "Kriteria Rumah Layak Huni,” 2020.

http://pembiayaan.pu.go.id/faq/p/category/kriteria-rumah-layak-huni (accessed May 29, 2021).

[2] BPPS, "Sistem Informasi Rujukan Statistik." https://sirusa.bps.go.id/sirusa/index.php/indikator/798 (accessed May 29, 2021).

[3] R. Indayu, "PEMBANGUNAN REHABILITASI RUMAH TIDAK LAYAK HUNI TERMASUK JAMBAN/ SANITASI KELURAGA OLEH PEMERINTAH DAERAH KABUPATEN KARIMUN DI KECAMATAN TEBING TAHUN 2012.”

https://media.neliti.com/media/publications/31352-ID-pembangunan-rehabilitasi-rumahtidak-layak-huni-termasuk-jamban-sanitasi-kelurag.pdf (accessed May 29, 2021).

[4] M. Guntur and R. Yanto, "Penerapan Metode SMART untuk Seleksi Kelayakan Penerima Bantuan Pengembangan Usaha Pangan Masyarakat," Telematika, vol. 12, no. 2, pp. 149-159, Aug. 2019, doi: 10.35671/telematika.v12i2.826.

[5] Faizal, F. A. Setyaningsih, and M. Diponegoro, "Implementasi Sistem Pendukung Keputusan dengan Metode SMART untuk Merangking Kemiskinan dalam Proses Penentuan Penerima Bantuan PKH ," Apr. 2017. doi: 10.26418/CODING.V5I2.19510.

[6] T. Magrisa, K. D. K. Wardhani, and M. R. A. Saf, "Implementasi Metode SMART pada Sistem Pendukung Keputusan Pemilihan Kegiatan Ekstrakurikuler untuk Siswa SMA," Informatika Mulawarman : Jurnal Ilmiah Ilmu Komputer, vol. 13, no. 1, p. 49, Feb. 2018, doi: 10.30872/jim.v13i1.648.

[7] Kusrini, Konsep dan Aplikasi Sistem Pendukung Keputusan. 2007.

[8] T. Magrisa, K. D. K. Wardhani, and M. R. A. Saf, "Implementasi Metode SMART pada Sistem Pendukung Keputusan Pemilihan Kegiatan Ekstrakurikuler untuk Siswa SMA ," Informatika Mulawarman : Jurnal Ilmiah Ilmu Komputer, 2018. http://ejournals.unmul.ac.id/index.php/JIM/article/view/648/pdf (accessed May 29, 2021). 
[9] T. Limbong and J. Simarmata, "Menentukan Matakuliah yang Efektif Belajar Daring (Belajar dan Ujian) dengan Metode Multi-Attribute Utility Theory (MAUT)," Jurnal Resti, vol. 4, no. 2, pp. 370-376, 2020.

[10] T. Limbong, J. Simarmata, M. Rofendi Manalu, A. Rikki, and D. M. Rajagukguk, "Implementation of Multi Factor Evaluation Process (MFEP) in Assessment of Employee Performance Achievement," Journal of Physics: Conference Series, vol. 1573, no. 1, 2020, doi: 10.1088/1742-6596/1573/1/012022.

[11] T. Limbong et al., Sistem Pendukung Keputusan: Metode \& Implementasi. Yayasan Kita Menulis, 2020. 